\title{
Changes in quantitative parameters of active wind dunes on the south-east Baltic Sea coast during the last decade (Curonian Spit, Lithuania)
}

\author{
Regina MORKŪNAITÉ ${ }^{1}$, Artūras BAUTRĖNAS ${ }^{2}$, Algimantas ČESNULEVIČIUS ${ }^{2,{ }^{*}}$, Nikita DOBROTIN², \\ Aldona BAUBINIENE' ${ }^{1}$, Margarita JANKAUSKAITE ${ }^{1}$, Audrius KALESNIKAS ${ }^{2}$ \\ and Neringa MAČIULEVIČIÜTĖ-TURLIENË ${ }^{2}$
}

1 Nature Research Centre, Institute of Geology and Geography, Akademijos 2, 08412 Vilnius, Lithuania

2 Vilnius University, Centre for Cartography, M.K. Čiurlionio 21/27, 03101 Vilnius, Lithuania

3 Klaipèda University, Herkaus Manto 84, 92294 Klaipèda, Lithuania

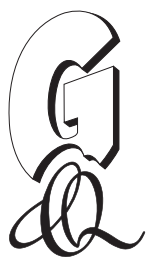

\begin{abstract}
Morkūnaitè, R., Bautrènas, A., Česnulevičius, A., Dobrotin, N., Baubinienè, A., Jankauskaitè, M., Kalesnikas, A., Mačiulevičiūtè-Turlienè, N., 2018. Geological Quarterly, 62 (1): 38-47, doi: 10.7306/gq.1389

The Curonian Spit is one of the largest Holocene sand accumulation forms, stretching along the Baltic Sea coast and belonging to the Baltic sand belt. This article deals with the dynamics of the Curonian Spit dunes in the context of global climate change. Investigations were carried out in the environs of two high dunes (Parnidis Dune and Naglis Dune) over a period of 10 years (2003-2014). Levelling of cross-sections was performed using modern geodesic devices. Wind velocities and directions were measured at meteorological stations of Klaipèda and Nida. The wind regime (number of days with winds $>15 \mathrm{~m} / \mathrm{s}$ ) was almost at the multiannual average during the study period. Sand moisture was measured in both dunes studied, and groundwater level was measured in the environs of the Naglis Dune by using ground penetrating radar (GPR). The Naglis Dune experienced a more significant lowering (by 4-6 m) compared with the Parnidis Dune over the study period, while sand deficit was greater in the Parnidis Dune $\left(\sim 10,000 \mathrm{~m}^{3}\right)$. Compared with other European sand dune systems, the Curonian Spit dunes have undergone strong degradation. The article highlights possible degradation reasons and indicates the necessity of additional investigations. Only long-term investigations can contribute to disclosing the main processes both as natural background and due to anthropogenic activities, and the devising of protection measures.
\end{abstract}

Key words: Curonian Spit, aeolian processes, coastal dunes, penetrating radar (GPR), dynamics.

\section{INTRODUCTION}

Dune systems are especially important where they protect high-density residential or industrial developments, high-grade agricultural land or habitats of international conservation importance. Compared with many other forms of defence, dunes are less visually intrusive, have greater value for wildlife and recreation, and are able to respond more readily to changes in environmental forcing factors (e.g., climate and sea level changes, sediment supply conditions; Tsoar and Møller, 1986; Battiau-Queney et al., 2001; Pye et al., 2007; Battiau-Queney, 2015). Their dynamics are understood in other works as occurring "within" and "between" habitats (Vermaat and Gilbert, 2006). The issue of dune dynamics in the Baltic region has received less attention than dune morphology, habitats and management (Miszalski, 1973; Łabuz, 2004; Olšauskas, 2009;

\footnotetext{
* Corresponding author, e-mail: algimantas.cesnulevicius@gf.vu.It

Received: May 29, 2017; accepted: July 5, 2017; first published online: November 2, 2017
}

Wojtanowicz, 2009; Łabuz et al., 2013). According to extensive literature (Gudelis and Kazakevičius, 1988a, b; Kazakevičius, 1988; Jarmalavičius and Žilinskas., 1996; Gudelis, 1998; Povilanskas et al., 2011), the Curonian Spit has no inflow of new sand; therefore, appropriate selection of effective measures for long-term dune protection is very important.

Investigations of Main Dune Ridge dynamics go back to the 19th century when efforts were made to stabilise sand movement towards the Curonian Lagoon (Berendt, 1869). Detailed palaeogeographic reconstructions of the formation of the Curonian Spit were shown by Kabailienè $(1967,2006)$. According to these reconstructions, a number of islands with a foundation of till deposits appeared in the place of the current Curonian Spit, and only later they geomorphologically merged as a single spit (Gelumbauskaitè and Šečkus, 2005; Gelumbauskaitè, 2010). Subsequent attempts to determine the spatial diversity of modern geomorphological processes on Dune Ridge (Povilanskas, 2009a, b) and the migration of a few dunes (Skilvytè and Apvalus Medis) in 1910-1955-1984 (Kazakevičius, 1988) were based on cartometric methods. The dynamics of the Nida dunes was also determined based on theodolite measurements (Mardosiene, 1988). According to boreholes drilled into the current Curonian Spit, the tills locally occur close to the ground surface, which differs from e.g. the Vistula 
Spit where the Pleistocene surface is located at $14-16 \mathrm{~m}$ below sea level (Mojski, 1988). Migrating dunes in the blown sand landscape were monitored for change, including the rates of overgrowing with vegetation (Morkūnaitè et al., 2016).

The Curonian Spit is the largest Holocene coastal sandy accumulation form developed along the Baltic Sea coast (Gudelis and Kazakevičius, 1988b). It is distinguished by exceptionally high dunes compared with postglacial dunes of other spits (e.g. Vistula Spit). Gudelis (1998), having considered the wide distribution of the so-called "lagoon marl" (i.e. organic-rich lagoon mud) beneath a significant part of the current Curonian Spit, made a prediction that at the very beginning of spit formation this sandy barrier was lying at a lower hypsometric level and more eastward than it is now (Sergeev et al., 2016). Holocene drift sands as an important component of the European Sand Belt, which stretches from Britain to the Ural mountain range, have been extensively described. The aerial extent of drift-sand fields in NW Europe is estimated to be 3000 to 4000 km (Koster, 2009; Jungierius and Riksen, 2010; Ratas et al., 2012, 2015). According to Peyrat (2011): "The only larger open migrating dune systems left today are three separate dune fields on the Curonian Spit and a vast area in the middle of the Leba Bar. There migrating dunes, both stabilised and unstabilised, reach a height of between $40 \mathrm{~m}$ (Leba Bar) and $60 \mathrm{~m}$ (Curonian Spit) ridges are among the most biggest and most active in Europe".

The dunes of the Curonian Spit extend over the territories of two countries; therefore, it is recommended to observe more uniform principles for nature management.

The flow of visitors to the Curonian Spit, increasing since the 1970s, has strongly affected the Main Dune Ridge. The Nagliai Reserve (established 1994) contributed to visitor flow control, yet did not fully resolve the problem of increasing anthropogenic loads on the environment.

The aim of the present study is to demonstrate 10-year (2004-2015) changes at the surface near the Parnidis $\left(0.9 \mathrm{~km}^{2}\right)$ and Naglis $\left(0.8 \mathrm{~km}^{2}\right)$ dunes, based on the character of climatic factors (wind velocity and direction) and groundwater distribution in a large part of the Curonian Spit. A comparison of the results of our long-term observations with multiannual investigations of coastal dunes in northern France (BattiauQueney, 2015) has revealed general tendencies of natural changes, the dominant influence of the natural background (abrasion, accumulative and aeolian processes on the coast) on the sensitivity of coastal areas and dunes, and the necessity to differentiate between different dune protective measures. We know that it is only by multiannual investigations that the almost full recovery of the protective dune structure after storms was demonstrated (Jarmalavičius et al., 2016). In this work, the possible effect of groundwater level differences at the selected objects was examined. The study is novel as it is the first time analysis of the 10-year dynamics of the Main Dune Ridge of the Curonian Spit based on levelling of the same cross-sections with precise geodetic devices. Thus, the present monitoring of dune dynamics, i.e. levelling along the same cross-sections, yielded important results showing that the changes occurring are related to climate change, anthropogenic impacts and groundwater fluctuations. The research provides detailed quantitative parameters (blown-off and blown-up sand amounts, dune height fluctuations, etc.) of changes in aeolian relief forms. This kind of information is important for accumulation segments of the Baltic Sea coast and Curonian Lagoon coast, transformed by aeolian processes.

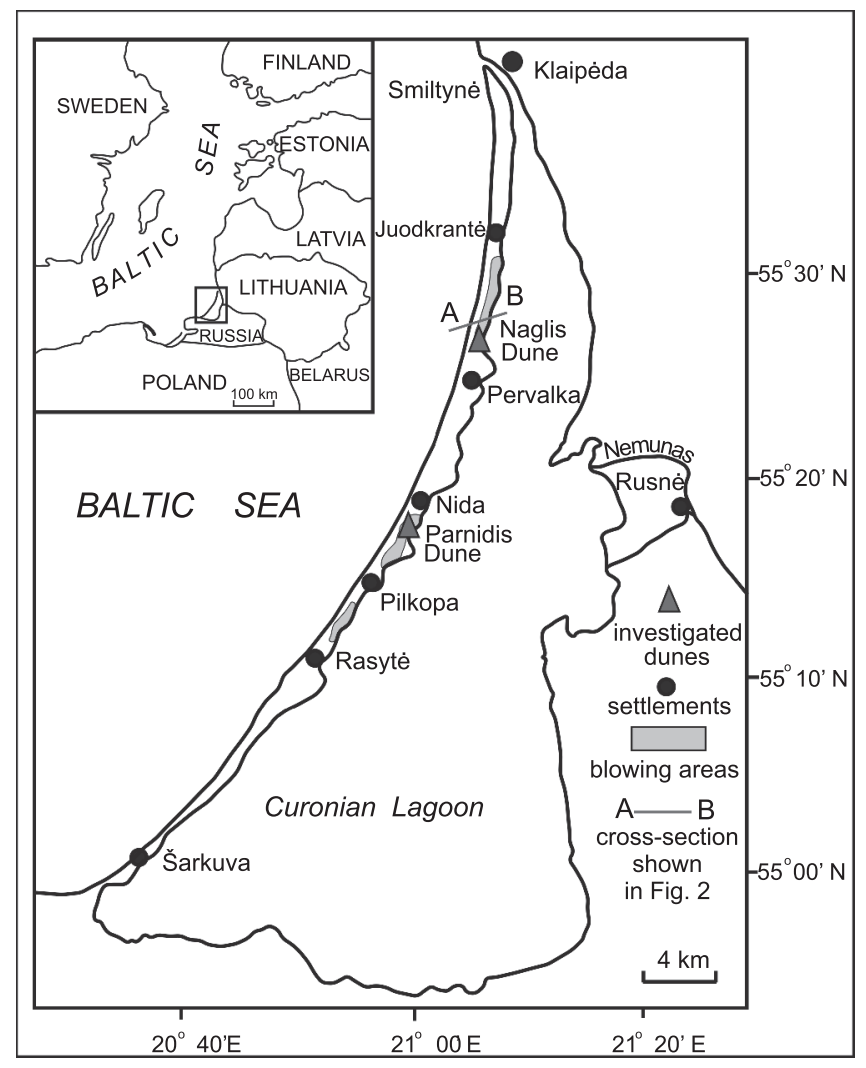

Fig. 1. Geographical location of the study area (the inset indicates the position in the East Baltic region)

\section{STUDY AREA AND GEOLOGICAL SETTING}

The Curonian Barrier Spit is the longest in the south-east part of the Baltic Sea coast (98 km long and up to $4 \mathrm{~km}$ wide). It stretches in a gentle curve south to the cliffed coast of the Sambian Peninsula (Fig. 1).

Most of the front dune ridges on the sea coast are artificial. The almost entire Curonian Spit has a foredune ridge $\sim 10-12 \mathrm{~m}$ in height and 70-120 m in width (Minkevičius et al., 1996). The deflation area called a "palve" (a sand-blowing flat or rough surface), which is covered by species-rich dry grasslands, stretches behind this dune ridge. Of its $1200 \mathrm{~m}$ wide strip in the year 1938 , only $50 \mathrm{~m}$ survived over 60 years. The main dune area is overgrown with trees or has been afforested (Stankevičiūtè, 2000). The Curonian Spit is well known for its large-scale shifting sand dunes. As has been pointed out by experienced researchers of aeolian processes (Livingstone and Warren, 1996), coastal dune formation is considerably complicated in most cases by geologically very recent and quite rapid changes in the conditions under which they form. These come from two directions - first, connected with climatic and sea level changes and, second, connected with interference by people.

With the help of modern geophysical and geochronological techniques; ground penetrating radar (GPR) surveys, LIDAR data, and radiocarbon $\left({ }^{14} \mathrm{C}\right.$ dating), detailed investigations of paleosols were carried out in the Dead (Grey) Dunes massif located between the Juodkrante and Pervalka settlements on the Lithuanian part of the Curonian Spit. Several soil-forming gen- 


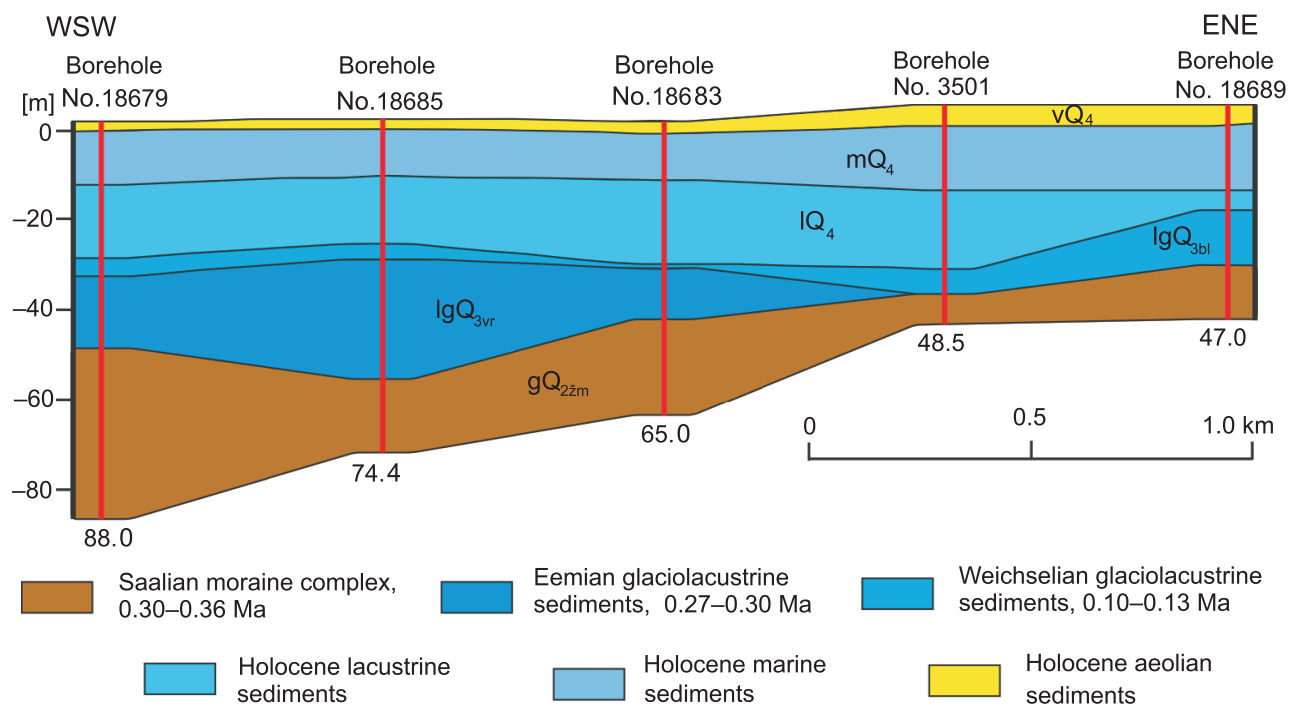

Fig. 2. Geological structure of the study area (the place of cross-section with this geological structure is described in Fig. 8)

erations (phases) during 5800-4500, 3900-3100, 2600-2400, and from 1900 calendar years BP until the present have been distinguished (Dobrotin et al., 2013). According to the cross-section made by Bitinas et al. (2000) near the study area, granular sand of marine sediments (5-10 $\mathrm{m}$ thick), glaciolacustrine sands and silts (10 $\mathrm{m}$ thick) lie below mobile dunes of the first and second generation (the thickness - or height - of which reaches $<20 \mathrm{~m}$ ), with glacial deposits lying at a depth of $30 \mathrm{~m}$ and deeper (Fig. 2). The Baltic lake sapropel is often only present near the Curonian Lagoon.

The most important and well-known site in the Curonian Spit National Park lies within the Nagliai Strict Reserve (Motiekaityte, 2000). It is covered by different successional stages of open sparsely distributed dry grasslands. The Nagliai Nature Reserve stretches for $9 \mathrm{~km}$ between the Juodkrante and Pervalka settlements. It has been established for the preservation of natural landscapes with sectors of the Main Ridge of grey dunes, with the blown-out remnant area and Agila and Lydumas capes, a forested hummocky palve, a foredune of the sea coast, and sand tracts. It was also designed for the protection of the habitats of flora and fauna included in the Red Data Book of Lithuania and of habitats of European importance. In 1675-1854, four Nagliai villages were buried under the sand. At that time, the shifting velocity of dunes was 0.5 to $15 \mathrm{~m}$ per year.

\section{METHODS}

In 2003-2004, dune altitudes, inclinations, and distances were measured by a Zeiss Elta R55 electronic theodolite. The target position of measured points was identified in the coordinate system in Lithuania, and altitudes were identified in the Baltic Height System. Measurements were made at an accuracy of $\pm 5 \mathrm{~cm}$. In 2014, measurements were taken by Trimble GPS equipment. Measurements were made in the LKS94 coordinate system: $X, Y \pm 0.070 \mathrm{~m} ; Z \pm 0.050 \mathrm{~m}$. A total of 2150 characteristic relief points were measured. Illustrative material of in- strumental investigations was compiled using the AutoCAD programme.

Meteorological data (wind directions and velocities for the period of 2003-2014) and precipitation data were obtained from the archives of the Lithuanian Hydrometeorological Service. The data from meteorological stations at Nida and Klaipeda were compared. The illustrative material (wind roses) were compiled using a programme developed by A. Bautrènas. Sand humidity (moisture) near the Parnidis and Nagliai dunes was measured by the method of weighing dishes. An Excel programme was used to calculate sand surface moisture and moisture at a depth of $0.15 \mathrm{~cm}$ according to the soil moisture formula. Sand moisture was indicatively compared on the windward and downwind slopes of the dunes by indicating sand moistures adequate to start drifting locally and substantially.

To determine the underlying factors of dune dynamics, we used records of groundwater investigations. Investigations by ground-penetrating radar were carried out by a contractor, UAB GeoBaltic, which holds a permit (No. 139, 29.04.2009) issued by the Lithuanian Geological Survey to investigate land subsurface and perform geophysical surveys. The GPR is a synthetic aperture radar (SAR) intended for subsurface reflection surveys: a short electromagnetic impulse is radiated into the study environment, and when the impulse reaches a layer or an object the relative dielectric permittivity of which differs from the environment, part of the impulse is reflected and goes back. When conducting surveys by a GPR it is important to know the speed of propagation of electromagnetic waves in the study object. Thus, the main parameters of the most widespread rocks, sediments and other physical media, i.e. relative dielectric permittivity, specific electric conductivity, speed of propagation of electromagnetic waves and suffocation coefficient, are presented. The GPR was used to measure groundwater depth near the Nagliai Dune (alongside, the GPR was used to determine the Main Dune Ridge groundwater occurrence isobars) and from boreholes (No. 26246) near the Parnidis Dune, as taken from Damušytè (2011). 

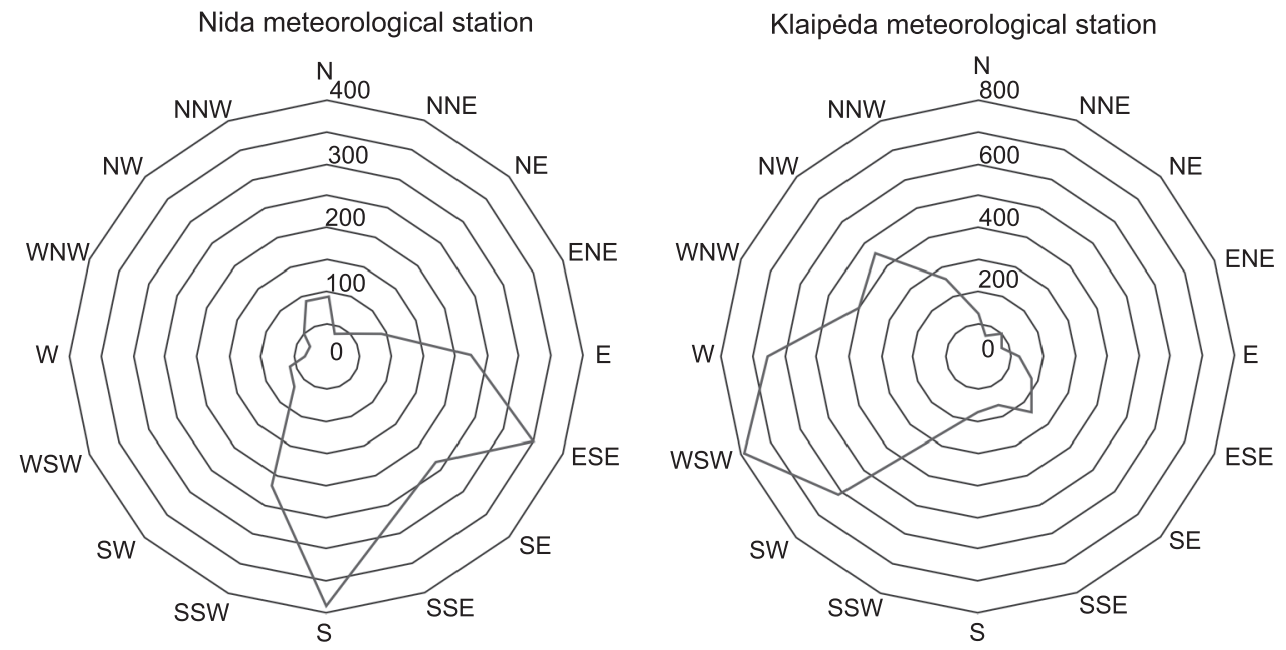

Fig. 3. Distribution of strong wind cases in warm seasons (March-October) during 2003-2014

The wind speed equals or is $\geq 6 \mathrm{~m} / \mathrm{s}$

\section{DISTRIBUTION OF WIND AND MOISTURE INDICES AND GROUNDWATER}

Winds were recorded (on a case-by-case basis) throughout the warm period of 2003-2014 according to data from meteorological stations in Klaipeda and Nida. Only winds $\geq 6 \mathrm{~m} / \mathrm{s}$ of March-October were analysed. WSW winds prevailed (16.8\%), followed by W winds (14\%), E winds (2.7\%), and S winds (3.7\%) (Fig. 3). Such cases constituted $13.7 \%$ of all winds. As per data from the meteorological station at Klaipeda, the number of days with winds stronger than $15 \mathrm{~m} / \mathrm{s}$ totalled 55 (16 per season). The recent decade was found to be "milder" as regards wind strength than the periods of 1993-2002 (63 days) or 1981-1990 (75 days). According to published data (Climate Atlas..., 2013), the Lithuanian coastal area had 30-35 days with winds stronger than $15 \mathrm{~m} / \mathrm{s}$, whereas middle and east Lithuania had only 5-9 such days. The number of days with winds stronger than $15 \mathrm{~m} / \mathrm{s}$ averaged 73 in Klaipèda, 60 in Nida, and 43 in Šilutè.

Dune sand moisture was measured by the method of weighing dishes in different dune profile areas, and comparison was made between sand moisture in the Parnidis Dune environs on 27 June 2015 (no precipitation) and in the Nagliai Dune environs on 23 June of the same year (amount of precipitation was $3.8 \mathrm{~mm}$ on 23 June and $8.2 \mathrm{~mm}$ on 22 June). In the western part of the Nagliai Dune, sand moisture reached $1.91-2.74 \%$ at the surface, and $1.83-2.39 \%$ at a depth of $10 \mathrm{~cm}$. On the nature trail, sand moisture was $0.22 \%$ at the surface, and $0.065 \%$ at a depth of $10 \mathrm{~cm}$. Such an inverse distribution may be due to human trampling. In May 2014, no moisture distribution inversion was detected at the sand surface nor in deeper layers: on 12 May (the amount of precipitation was $0.0 \mathrm{~mm}$ on 11 May and $2.8 \mathrm{~mm}$ on 10 May) near the nature trail up the Nagliai Dune (where there are fewer visitors) sand moisture reached $3.41 \%$ at the surface, and $5.04 \%$ at a depth of $15 \mathrm{~cm}$. The sand moisture measurement data obtained near the Parnidis Dune on 27 June 2015 (no precipitation) were more consistent, because in the western part of the slope there was a tussock area where sand contained more moisture (by 1-2\%) than the sand near the Sun Clock.

The GPR scanning data from the Nagliai Dune environs showed that the groundwater horizon was at a depth of 1-2 $\mathrm{m}$ closer to the top of the Nagliai Dune from the side of the sea, and at a depth of 20-30 $\mathrm{m}$ at the toe of the dune. As we can see in Figure 4, the groundwater level under the Nagliai Dune disappears (the device does not detect it). According to the borehole at Nida, the groundwater horizon near the Parnidis Dune was at a depth of $0.5 \mathrm{~m}$, and its presence under the Parnidis Dune was not identified (Bendoraitis and Saulis, 1997).

\section{RESULTS}

DYNAMICS OF THE PARNIDIS DUNE

The measured data obtained in the spring-autumn of 2003-2004 showed that increasing flows of visitors to the Parnidis Dune (Fig. 5A) and to the nature trail in the Nagliai Nature Reserve contribute to the strengthening of the natural deflation processes. The present article outlines the seasonal patterns of aeolian deflation-accumulation processes and presents a quantitative evaluation of the scale of aeolodynamics. The sand balance is similar to that in the entire southern and southeastern coastal area of the Baltic Sea (Furmańczyk, 1995; Aagaard et al., 1998, 2004; Christiansen et al., 2002; Christiansen and Davidson-Arnott, 2004; Grunewald, 2006; Hoffmann and Lampe, 2007; Łabuz, 2013; Rotnicka, 2011a, b).

A comparison of the data from measurements obtained in 2003-2004 and $\sim 10$ years before showed that the eastern part of the Parnidis Dune top did not undergo changes during the summer time. Somewhat more pronounced changes took place in the longer eastern part of the slope falling away towards the first (main) dune edge. The shape of this slope transformed from almost straight to convex-concave. Drifts and blowouts reached from 0.2 to $0.8 \mathrm{~m}$ (Česnulevičius et al., 2006; Izmaiłow, 2006, 2009; Morkūnaitè et al., 2017).

The most dramatic changes occurred on the eastern part of the lower slope. In the summer of 2003, winds eroded this part of the slope. Its altitude decreased by $\sim 0.4-0.6 \mathrm{~m}$. During the winter time, a terrace accumulated. In the summer of 2014, the upper part of the terrace was eroded. The thickness of the eroded layer was $0.4-0.8 \mathrm{~m}$. The edge of the lower part of the terrace moved $1 \mathrm{~m}$ towards the lagoon because of sand accumulation. The southeastern winds could have blown sand up the dune. The anthropogenic trampling in 2004 was reduced by building a fence around part of the slope. 


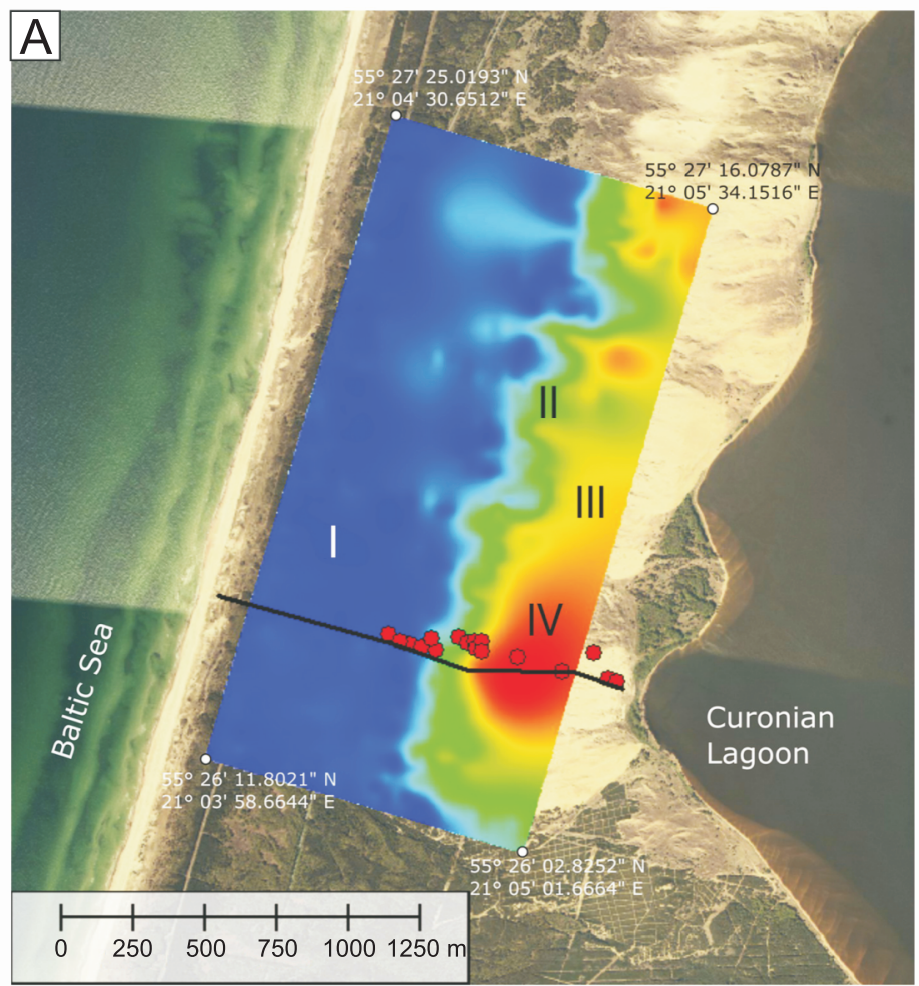

B $[\mathrm{m}]$
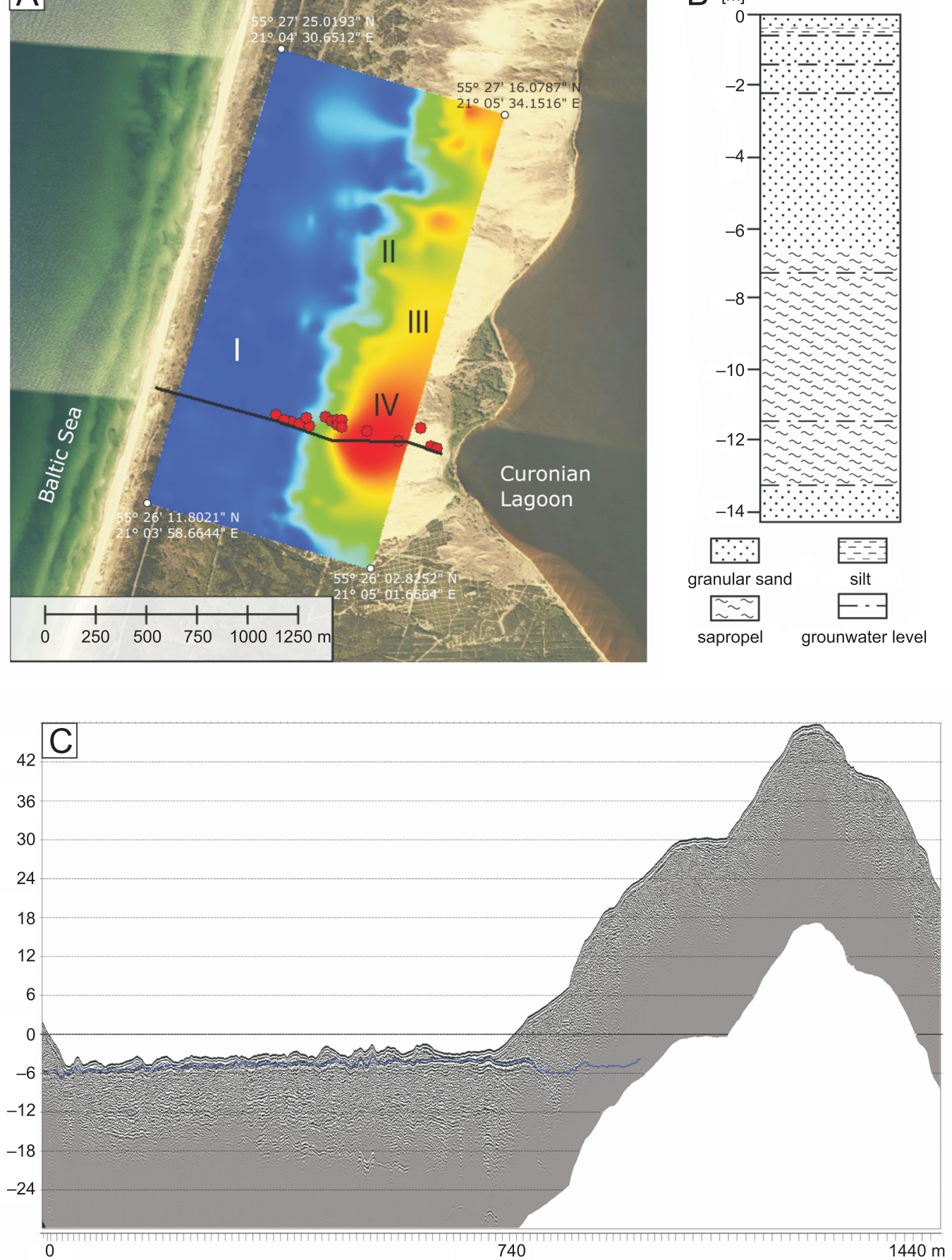

Fig. 4. Distribution of groundwater in study areas

A - part of study areas near the Nagliai Dune; it is the place of cross-section in the Naglis Dune and the depth of groundwater level: I - 1-3 m, II - 3-7 m, III - 7-11 m, IV - 11-15 m; B - borehole near Parnidis; C - scanning profile by GPR in the Naglis Dune in which the level of groundwater is seen

A comparison of the data in Figure 6 demonstrates that the upper part of the eastern slope lowered by $2-2.5 \mathrm{~m}$ due to trampling. Now, the slope is convex-concave. A small 2-2.5 $\mathrm{m}$ high terrace developed in its middle part. This occurred in the figured profile (Fig. 6) during the winter, suggesting that a detailed investigation of slope erosion during winter is necessary in the early spring. Investigations of snow cover impacts should be performed in relation to global climate change, because it is clear that snow amount on the dunes has decreased.

According to the data from a longer investigation period (2003-2014) on the lower part of the slope, hummocky sand slides up to $0.7 \mathrm{~m}$ in height and up to $9.87 \mathrm{~m}$ in length could be 

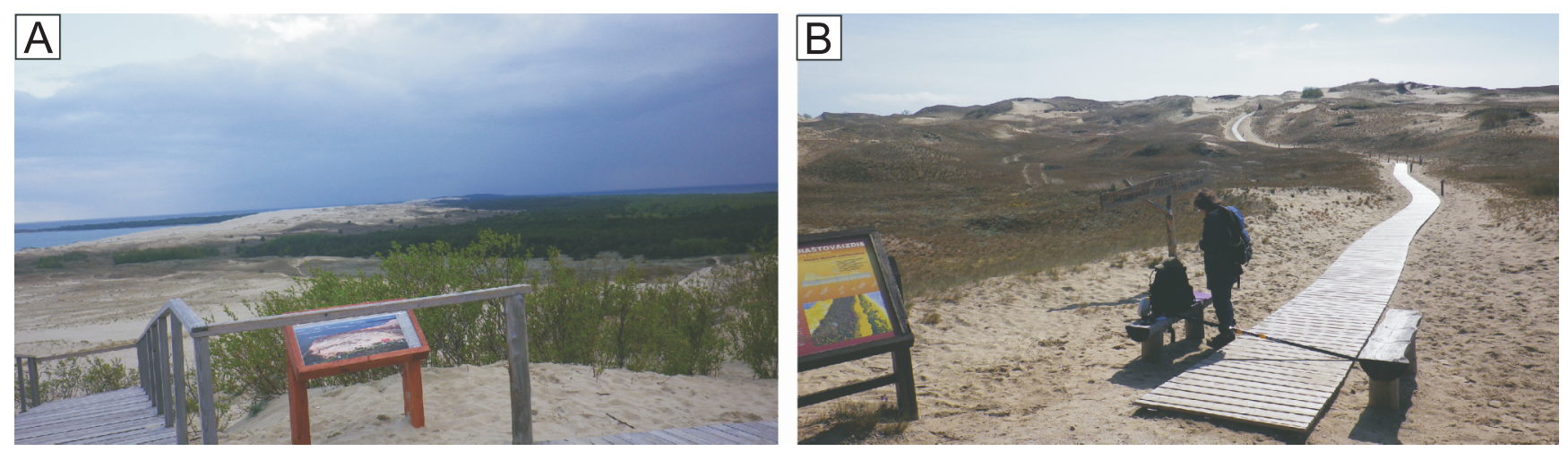

Fig. 5A - scenery from the Parnidis Dune towards the lagoon; B - path to the Naglis Dune

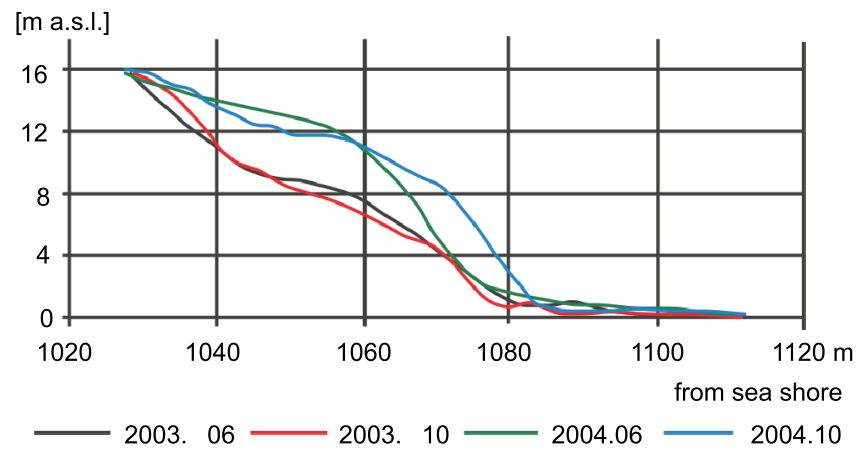

Fig. 6. Changes that occurred in the eastern slope of the Parnidis Dune in 2003-2004 observed (Fig. 7A and B). The sand slides were presumably generated by paths at the slope bottom. The loss of sand reached $\sim 10,000 \mathrm{~m}^{3}$ (Fig 7C), which was due to anthropogenic load in the western part of the dune ("Sun Clock" stone monument on Parnidis Dune top, asphalt paths), because sand flow transit decreased.

According to the GPS measuring data obtained in 2008, the trampled areas amounted to 25.7 ha $(11.2 \%$ of the total area of the Parnidis Reserve; Morkūnaitè et al., 2012). It was determined that due to degradation of the shifting dunes in the second half of the 20th century, the Parnidis Dune and the Parnidis Cape lost an area of 89.1 ha (24.39\%). From 1955 to 2000 , the Parnidis Dune was lowered from 55 to $43 \mathrm{~m}$ (Povilanskas et al., 2009). Just behind the Sun Clock, the observed lowering constituted approximately $2.05-3 \mathrm{~m}$. This observation is in agreement with the findings of other researchers (Povilanskas et al., 2009) and shows the tendency of an even decrease of dune height.

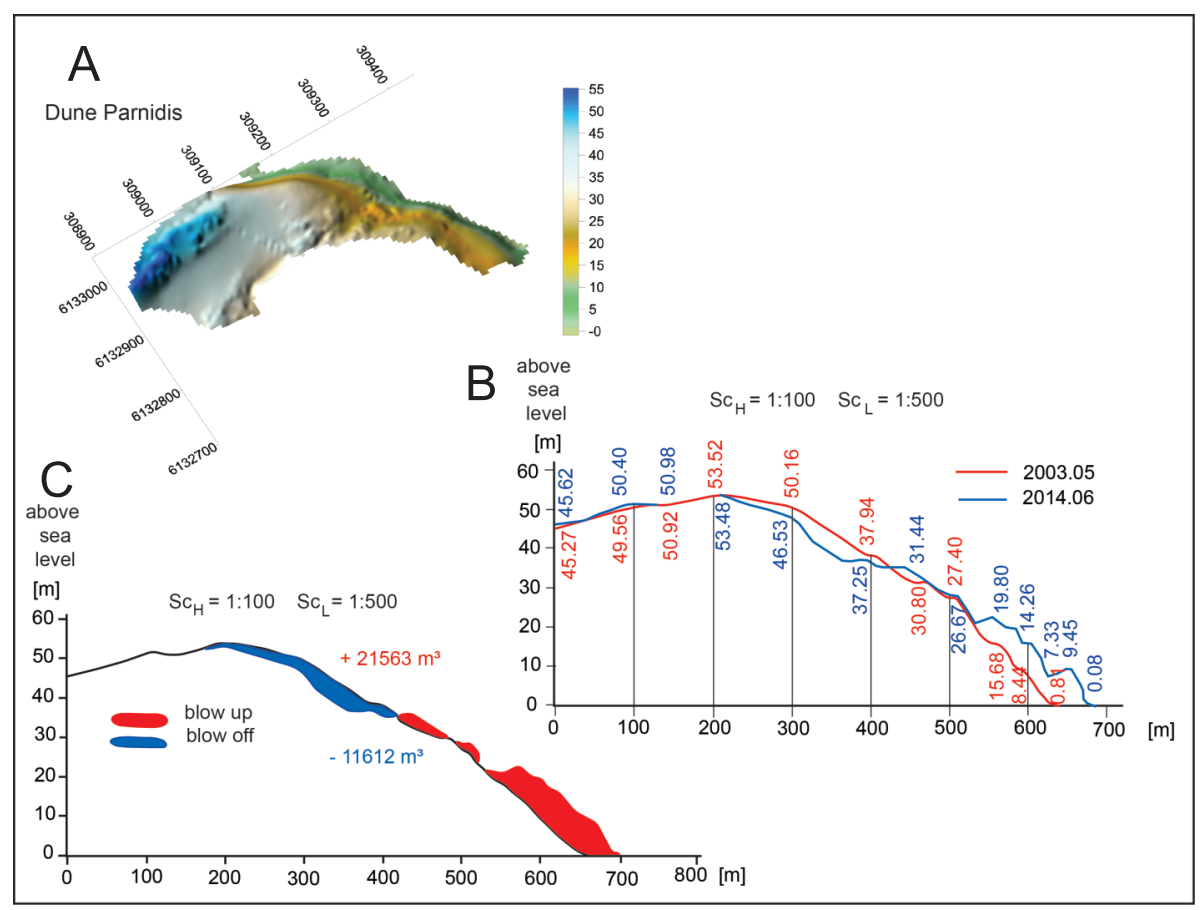

Fig. 7. Comparative dynamics of the Parnidis Dune in cross-section (B) and 3D model of surface in 2015 (A) and the balance of aeolian outwash (C) in 2003-2013 


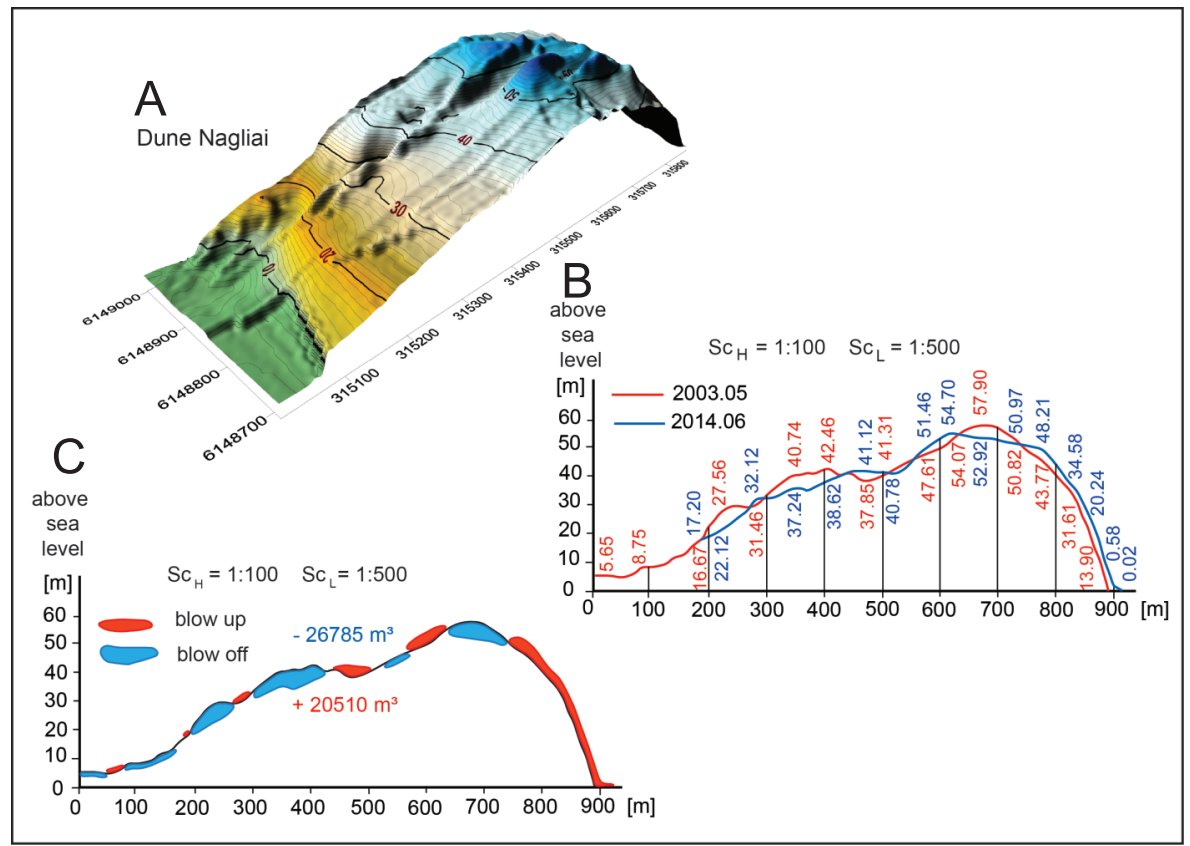

Fig. 8. Comparative dynamics of the Nagliai Dune in 3D model (A) in 2016 and cross-section of its surface (B) and the balance of aeolian outwash (C) in 2003-2014

DYNAMICS OF THE NAGLIAI DUNE

A comparison of the Nagliai Dune (Fig. 8B) levelling data from 2003 and 2014 showed that in 2014 the surfaces in its western part were lower by 1.5-2 $\mathrm{m}$ at the toe of the profile, by 4-6 $\mathrm{m}$ in its middle (with the "truncated" dome-shaped terrace), and by $3-5-6 \mathrm{~m}$ in its upper part, where thee is a repetition of a step-like surface. The top was visibly lower by $5 \mathrm{~m}$, whereas the advance of the eastern slope facing the lagoon was 4-6 $\mathrm{m}$. The differences in the altitudes of surfaces were very pronounced and not only revealed a trend of dramatic lowering (from 57.9 to $52.9 \mathrm{~m}$ at the top) but also disclosed variable wind erosion patterns on the lower, middle and upper parts of the slope. For example, the toe is a place where slope angle, shear stress and sand discharge all change abruptly. Most observations and models show that velocity decreases at the toe (Jensen and Zeman, 1985; Livingstone, 1986). Theory suggests that this is because the flow is backed up against the slope. The main slope is a zone which, as Bagnold (1954) showed, must be the zone of the greatest erosion if the shape of the dune is to be preserved as it advances (Livingstone and Warren, 1996).

Our investigations into the dynamics of the Nagliai Dune revealed that $\sim 6000 \mathrm{~m}^{3}$ of sand in the balance of aeolian outwash was lost (Fig. $8 \mathrm{C}$ ), which might be due to a long eastern track of dune sand transfer ( $400 \mathrm{~m})$. Other factors are also possible.

As generalized by known specialists in aeolian processes (Pye and Tsoar, 1990; Pye et al., 2007; Peyrat, 2007), erosional processes are of several types and include deflation of loose sediments due to direct wind drag, entrainment of loose sediments by impacting grains in the wind stream, and abrasion of hard surfaces by particles entrained in the flow. Nordstrom et al. (1986) also discussed dune degradation. The influence of vegetation cover on Curonian Spit dune development was observed by Lithuanian foresters and land managers (Povilanskas et al., 2011).

It is interesting that the Nagliai Dune (Fig. 8B) is an old dune first mentioned in 1735 (Betgen, 1735). Its active erosion appears to be controlled by trampling.
The velocity of dune movement in the northern part of Sylts (Listland), compared with the Łeba or Curonian Spit dunes, is 3-15 m per year (Mader, 1995). At the beginning of the 21th century, the yearly advance of open sand dunes amounted to $10 \mathrm{~m}$ (from April to September). Borówka (1980) observed in the Łeba dunes and Gudelis and Kazakevičius (1988b) in the Curonian Spit not only the falling height of open sand dunes, but also the decreasing surface angles.

Our suggestion is that blow-out processes are more active in the lower part of the western slope of the Naglis Dune, whereas in its upper part they are accompanied by accumulation that causes the formation of a step-like or terraced surface. Wind is the main driving force. Other factors, such as the character of the soil of the eroded surface (wet or dry), transitional surface, height above the ground, and position in the windward slope are passive, yet they considerably affect the amount of drifted sand (Minkevičius, 1969).

\section{DISCUSSION}

We compared the scale of blowout in Nagliai and Parnidis dunes and determined the following differences: the Nagliai Dune became lower by $\sim 5 \mathrm{~m}$ during 10 years, and the Parnidis Dune, being behind the Sun Clock, by $2-2.5 \mathrm{~m}$ during 10 years. Both dunes serve as recreational areas for people; therefore, they are exposed not only to natural factors, such as wind, rain, groundwater, aeolian sand properties, but also to human trampling. The groundwater distribution data show that near the Parnidis Dune the groundwater is closer to the surface and the aeration zone is narrower, therefore more precipitation permeates through it. Though both dunes are exposed to trampling, such explanations about blowout differences reflecting precipitation soaking more easily into the groundwater near Parnidis are logical. A very important index of resistance of the aeolian surface is the granulometric composition to be investigated in the future. To date, the granulometric composition of aeolian sand has been investigated in some places only (Česnulevičius 
and Morkūnaitè, 1998), because there are not many longitudinal profiles to determine the parameters of granulometric composition through the Great Dune Ridge. Some data are available on the granulometric composition of coastal beaches (e.g., Jarmalavičius and Žilinskas, 1996; Žilinskas et al., 2001). Some general descriptions say that further to the south, from Juodkrantë to Nida, the beach is mainly composed of medium-grained sand (in the range of $0.25-0.35 \mathrm{~mm}$; Žilinskas et al., 2001).

As our work mainly focused on the estimation of dune degradation trends rather than on causality, the granulometric composition of aeolian sand was not analysed. From earlier works we know that in the Great Dune Ridge, the parameters of granulometric composition are within the range of deposits of the Middle Lithuanian, North Lithuanian, and Holocene glaciation phases. It was determined that $0.1-0.25 \mathrm{~mm}$ particles prevailed $(60.79 \%)$ in the dunes of the Middle Lithuanian phase, followed by $53.26 \%$ and $45.20 \%$ in the dunes of the North Lithuanian and Holocene glaciation phases, respectively. A large part of the sand fraction (30-40\%) is composed of $0.25-0.5 \mathrm{~mm}$ particles, which is typical of the Curonian Lagoon coastal dunes. There is a third tendency that the amount of coarser particles increases moving from east to west (Česnulevičius and Morkūnaitè, 1997, 1998). Such tendencies are conditioned not only by deflation and accumulation processes, but also by the granulometric composition of the surface layer of dune sand. Therefore, it is presumed that differences in the blowout of Parnidis and Nagliai dunes are also possible because of differences in the granulometric composition of sand; however, a more detailed lithological analysis is necessary to test this idea. It is known from the hypotheses about the formation of the Curonian Lagoon that in the period before the Holocene there were chains of islands which later merged. We can initially presume that the existing channels had different sedimentation modes which might affect the granulometric composition of dunes (Žilinskas et al., 2016). The groundwater distribution schemes show that groundwater is closer to the surface in the environs of Nida and near Parnidis and by $0.5-1.5 \mathrm{~m}$ deeper near the Nagliai Dune; therefore, their impact is unquestionable. It is clear that similar investigations of dune dynamics show tendencies of rapid eastward movement of sand, and such a situation changes the position of the Main Dune Ridge and the basin of the Curonian Lagoon. The reconstruction of the Curonian Spit (Dobrotin et al., 2013) revealed the former position of the Curonian Lagoon in the period of soil formation - it was in the place of the current western slope of the Main Dune Ridge.

More detailed microclimatic investigations of dune surface and snow cover evaluations are necessary, which would facilitate the creation of a dune development and degradation model and help identify the main factors related to degradation. Degradation differences of the Nagliai and Parnidis dunes show that though the dunes are not very far from each other $(\sim 20 \mathrm{~km})$, their development was conditioned by the dominance of different factors. Parnidis' slopes are affected by anthropogenic load, while Nagliai Dunes are influenced by relief inclinations, a greater distance from the forest $(700 \mathrm{~m})$, and groundwater beneath $(\sim 1.5 \mathrm{~m})$. A comparison with Atlantic coastal dunes (north France; Battiau-Queney et al., 2001), to which sediments are brought from the sea and via spits (Listland, Vistula), shows that in the our studied dunes the degree of blow-off was different yet exceeded medium hazard levels; therefore losses should be regulated using different measures (the distance between the Nagliai and Parnidis dunes is $\sim 20 \mathrm{~km}$ ). Multiannual stationary observations confirm in large part the particular features of the natural background.

Such results support the previous results of palaeoreconstruction of the Curonian Spit, according to which 3,000 years ago the Curonian Lagoon was situated near the western slope of the Great Dune Ridge. The area of the lagoon is gradually decreasing due to a shortage of sand inflow from the Sambian Peninsula.

\section{CONCLUSIONS}

The dunes in the Lithuanian part of the Curonian Lagoon are known as mobile large-amplitude dunes; therefore, investigations of the dynamics of the active Nagliai (Nagliai Strict Reserve) and Parnidis (Parnidis Landscape Reserve) dunes during 2003-2014 are relevant in view of global climate change, because change to these sensitive dunes can be regarded as an indicator of climate change.

In the period of 2003-2014, wind indices (days with winds stronger than $15 \mathrm{~m} / \mathrm{s}$ ) were below the average (55 days according to the data of the meteorological station at Klaipeda against the average multiannual value of 60 days); however, deflation and accumulation processes in the dunes were more intense. Investigation of snow cover and snow melt rate effects are recommended, as well as microclimatic observations, and these should contribute to a more thorough investigation of potential hazardous impacts in each part of the Great Done Ridge.

Changes in groundwater distribution mean there is a narrower aeration zone near the Parnidis Dune and a greater precipitation impact on moisture retention at the surface of the aeolian sand and deeper. The Nagliai Dune is thought to undergo more marked degradation (the sediment deficiency is about twice the deficiency in the Parnidis Dune ) not only because of human trampling, but also because of a low groundwater level, some 1.5-2 m lower than near the Parnidis Dune.

Investigations of dune dynamics in 2003-2014 revealed a considerable tendency of dune lowering. The Nagliai Dune became lower by $5 \mathrm{~m}$ at its top and moved by $4-6 \mathrm{~m}$ in its eastern part. The Parnidis Dune became lower by $2-2.5 \mathrm{~m}$ behind the Sun Clock and moved by $9.87 \mathrm{~m}$ in its eastern part. During 2003-2004, the form of the Parnidis Dune's eastern slope changed from linear to incurved or outcurved. The lowering of the Nagliai Dune was greater by $5 \mathrm{~m}$ than the lowering of the Parnidis Dune, which can be explained by the Sun Clock and anthropogenic load in the western slope of the Parnidis Dune, a longer wind transit and longer annual investigation period.

A comparison with another coastal dunes shows that in the dunes of this study the degree of blow-off was different yet exceeded medium hazard levels while losses should be regulated by taking differentiated measures. Our stationary observations support for the major part the particular features of the natural background.

Acknowledgements. We are grateful to the programme "GEOSYSTEMS" financed by the Lithuanian Ministry of Education and Sciences. Special thanks are addressed to the Geological Quarterly reviewers and to the translator, V. Žalènienè. 


\section{REFERENCES}

Aagaard, T., Nielsen, J., Davidson-Arnott, R., Greenwood, B., 1998. Coastal morphodynamics at Skallingen, SW Denmark: high energy conditions. Danish Journal of Geography, 98: $20-30$.

Aagaard, T., Davidson-Arnott, R., Greenwood, B., Nielsen, J., 2004. Sediment supply from shoreface to dunes: linking sediment transport measurements and long term morphological evolution. Geomorphology, 60: 205-224.

Bagnold, R.A., 1954. The Physics of Blown Sand and Desert Dunes. Mehuen, London.

Battiau-Queney, Y., 2015. The dunes of Merlimont (North of France): a natural museum of aeolian landforms. Dynamiques Environnementales, 33: 51-64.

Battiau-Queney, Y., Fauchois, J., Deboudt, P., Lanoy-Ratel, P., 2001. Beach-dune systems in a macrotidal environment along the northern French coast (English Channel and Southern North Sea). Journal of Coastal Research, Special Issue, 34: 580-592.

Bendoraitis, A, Saulis, K., 1997. Curonian Spit: drinking water resources and quality. Geological Horizons, 2: 26-32.

Berendt, G., 1869. Geologie des Kurischen Haffes und seiner Umgebung. Königsberg.

Betgen, J.F., 1735. Lithuaniam Borussicam in qua loca. Map. Typescript.

Boròwka, R.K., 1980. Present day dune processes and dune morphology on the Leba Barrier, Polish coast of the Baltic. Geografiska Annaler: Series A, Physical Geography (A), 62: $75-82$.

Bitinas, A., Damušytè, A., Hutt, G., 2000. Stratigraphic correlation of Late Weischelian and Holocene deposits in the Lithuanian Coastal Region. Proceedings of the Estonia Academy of Science. Geology, 49: 200-217.

Christiansen, M.B., Davidson-Arnott, R., 2004. Rates of landward sand transport over the foredune at Skallingen, Denmark and the role of dune ramps. Danish Journal of Geography, 104: 31-43.

Christiansen, M.B., Edelvang, K., Emeis, K., Graf, G., Jahmlich, S., Kozuch, J., Laima, M., Leipe, T., Loffler, A., Lund-Hansen, L.C., Miltner, A., Pazdro, K., Pempkowiak, J., Shimmield, G., Shimmield, T., Smith, J., Voss, M., Witt, G., 2002. Material transport from the nearshore to the basinal environment in the southern Baltic Sea I. Processes and mass estimates. Journal of Marine Systems, 35: 133-150.

Climate Atlas of Lithuania, 2013. Lithuanian Hydrometeorological Service, Vilnius.

Česnulevičius, A., Morkūnaitè, R., 1997. Morphometrical, lithological and mineralogical traits of aeolian formations in the Lithuanian coastal zone of the Baltic Sea. Baltica, 10: 53-58.

Česnulevičius, A., Morkūnaitè, R., 1998. Some aspects of comparative characteristics of old and new generations of the Curonian Spit dunes. The Geographical Yearbook, 31: 200-210.

Česnulevičius, A., Izmaiłow, B., Morkūnaitè, R., 2006. Defliaciniu daubu dynamika Kuršiu nerijos Didžiajame kopagubryje (in Lithuanian). Geografija, 42: 21-28.

Damušytè, A., 2011. Post-glacial geological history of the Lithuanian coastal area. Ph.D. thesis, Vilnius.

Dobrotin, N., Bitinas, A., Michelevičius, D., Damušytè, A., Mažeika, J., 2013. Reconstruction of the Dead (Grey) Dune evolution along the Curonian Spit, Southeastern Baltic. Bulletin of the Geological Society of Finland, 85: 53-64.

Furmańczyk, K., 1995. Coast changes of the Hel Spit over the last 40 years. Journal of Coastal Research, Special Issue, 22: 193-196.

Gelumbauskaitè, L.Ž., 2010. Paleo-Nemunas delta history during the Holocene time. Baltica, 23: 109-116.

Gelumbauskaitè, L.Ž., S̄ečkus, J., 2005. Late Glacial-Holocene history in Curonian Lagoon (Lithuanian sector). Baltica, 18: $77-82$.
Grunewald, R., 2006. Assessment of damages from recreational activities on coastal dunes of the southern Baltic Sea. Journal of Coastal Research, 22: 1145-1157.

Gudelis, V., 1998. The Lithuanian offshore and coast of the Baltic sea. Academia, Vilnius.

Gudelis, V., Kazakevičius, S., 1988a. Some data on the structure and development of sand drifting in Curonian Spit (literature overview). Proceedings of Oceanology Institute of Academy of Sciences USSR, 10: 62-69.

Gudelis, V., Kazakevicius, S., 1988b. Some regularities in development of the Kuršiu nerija spit dunes and the bay coast according to cartometrical data (in Russian). Lituvos TSR Mokslu Akademijos darbai, Serija B, 165: 136-144.

Hoffmann, G., Lampe, R., 2007. Sediment budget calculation to estimate Holocene coastal changes on the southwest Baltic Sea (Germany). Marine Geology, 243: 143-156.

Izmaiłow, B., 2006. Rola wiatru w rozwoju Mierzei Kurońskiej (in Polish). In: Klimatyczne aspekty środowiska geograficznego (ed. Z. Olecki): 303-310. Instytut Geografii i Gospodarki Przestrzennej UJ, Kraków.

Izmaiłow, B., 2009. Warunki i skutki działalności człowieka na wydmach Mierzei Kurońskiej (in Polish). In: Ekosystemy piaszczyste i człowiek (eds. R.Dulias, J. Pełka-Gościniak and O. Rahmonov): 96-102. Wydział Nauk o Ziemi UŚ, Sosnowiec.

Jarmalavičius, D., Žilinskas, G., 1996. Distribution peculiarities of granulometrical composition of surface sediments on the Lithuanian Baltic coast. Geography, 32: 77-84.

Jarmalavičius, D., Žilinskas, G., Pupienis, D., 2016. Kuršiu nerijos prieškopiu vystymasis ir kaita skirtingose laiko skalèse (in Lithuanian). In: Kuršiu nerijos kraštovaizdžio pokyčiai (eds. A. Feser, R. Pakalnis, G. Raščius, L. Žarnauskas and L. Motuzienè): $39-49$. Neringa.

Jensen, N.O., Zeman, O., 1985. Perturbation in mean wind and turbulence in flow over topographic forms. Proceedings of International Workshop on the Physics of Blown Sand. University of Aarhus, Memoir, 8: 351-368.

Jungerius, P.D., Riksen, M.J.P.M., 2010. Contribution of laser altimetry images to the geomorphology of the Late Holocene inland drift sands of the European Sand Belt. Baltica, 23: 59-70.

Kabailienè, M., 1967. The development of the Spit of the Kuršiu Nerija and the Kuršiu Marios Bay (in Russian with English summary). Transaction of Institute of Geology, 5: 181-207.

Kabailienè, M. 2006. Gamtinès aplinkos raida Lietuvoje per 14000 metu (in Lithuanian). Vilnius University Press, Vilnius.

Kazakevičius, S., 1988. Dynamics of shore development on the Kuršiu Nerija spit (cartometrical analysis). The Geographical Yearbook, 25-26: 46-56

Koster, E.A., 2009. The "European Aeolian Sand Belt": Geoconservation of drift sand landscapes. Geoheritage, 1: 93-110.

Livingstone, I., 1986. Geomorphological significance of wind flow patterns over a Namib linear dune. In: Aeolian Geomorphology (ed. W.G. Nickling): 97-112. Allen and Unwin, Boston.

Livingstone, I., Warren, A., 1996. Aeolian Geomorphology: an introduction. Longman, Harlow.

Łabuz, T.A., 2004. Wydmowy krajobraz wybranych miejscowości nadmorskich zachodniego i środkowego wybrzeża Polski (in Polish). In: Stan środowiska społecznego podstawowym warunkiem zdrowotności społeczeństwa: 291-303. Uniwersytet Szczeciński, Optimex.

Łabuz, T.A., 2013. Polish coastal dunes - affecting factors and morphology. Landform Analysis, 22: 33-59.

Łabuz, T.A., Wochna-Bartnik, S., Osóch, P., Sławińska, J., 2013. The FoMoBi research project and its importance in the diagnosis of the contemporary dynamics and biodiversity of the foredunes on Polish coast (in Polish with English summary). Geologia i Geomorfologia, 10: 81-98.

Mader, D., 1995. Aeolian and adhesion morphodynamics and phytoecology in resent coastal and inland sand and snow flats 
and Dunes from mainly North Sea and Baltic Sea to Mars and Venus. North Sea and Baltic Sea, 1. Frankfurt/Main.

Mardosienè, D., 1988. Dynamics of mobile dunes of Kuršių Nerija spit. The Geographical Yearbook, 25-26: 18-45.

Minkevičius, V., 1969. The dependency of the quantity of sand transport from the meteorological conditions in the migrating dunes of the Kursiu nerija. The Geographical Yearbook, 10: 187-195.

Minkevičius, V., Žilinskas, G., Jarmalavičius, D., 1996. Morphodynamic evaluation of protecting dune of Curonian Spit. The Geographical Yearbook, 29: 63-74.

Miszalski, J., 1973. Współczesne procesy eoliczne na Pobrzeżu Słowińskim. Studium fotointerpretacyjne. PAN, Instytut Geografii, Warszawa.

Mojski, J.E., 1988. Development of the Vistula River Delta and evolution of the Baltic Sea, an attempt to chronological correlation. Geological Survey of Finland, Special Paper, 6: 39-45.

Morkūnaitè, R., Karmaza, B., Bauža, D., 2012. Determining the damage inflicted by tourists to the National Park of Curonian Spit and preventive measures for dunes. Ekologia (Bratislava), 31: 341-353.

Morkūnaitè, R., Radžūnienè, J., Navickas, K., Gudynienè, V., Bautrènas, A., 2016. Assessment of degradation of white and grey dune habitats in the Curonian Spit: a case study of Parnidis Dune (Nida environs, Lithuania). Zeitschrift für Geomorphologie, 60: 75-87.

Morkūnaitè, R., Bautrènas, A., Česnulevičius, A., 2017. The recent investigations and providences about active Aeolian forms in Curonian Split (Lithuania). Acta Geographica Silesiana, 25: 23-29.

Morkūnaitè, V., 2000. Changes sand dune plain communities of the Lithuanian coastal zona in the 20th century. Ekologija (Vilnius). 1: 7-15.

Nordstrom, K.F., McCluskey, J.M., Rosen, P.S., 1986. Aeolian processes and dune charasteristics of a developed shoreline: Westhampton Beach, New York. In: Aeolian Geomorphology (ed. W.G. Nickling): 131-147. Allen and Unwin, Boston.

Olšauskas, A.M., 2009. The Europe Shores. Klaipèda University Press, Klaipèda.

Peyrat, J., 2007. Development, properties and classification of dune soils in the Curonian Spit National Park, Russian part. Geologija, 59: 59-64.

Peyrat, J., 2011. Landscape and vegetation of southern Baltic dune systems: diversity, landuse changes and threats. Dissertation. University of Kiel.

Povilanskas, R., 2009a. Landscape management on the Curonian spit. A cross-border perspective. EUCC - The Coastal Union. Leiden-Klaipèda-Barcelona.

Povilanskas, R., 2009b. Spatial diversity of modern geomorphological processes on a Holocene Dune Ridge on the Curonian Spit in the South-East Baltic. Baltica, 22: 77-88.
Povilanskas, R., Baghdasarian, H., Arakelyan, S., Satkūnas, J., Taminskas, J., 2009. Secular morphodynamics trends of the Holocene dune ridge on the Curonian Spit (Lithuania/Russia). Journal of Coastal Research, 25: 209-215.

Povilanskas, R., Riepšas, E., Armaitienè, A., Dučinskas, K., Taminskas, J., 2011. Shifting dune type of tha Curonian Spit and factors of their development. Baltic Forestry, 17: 215-226.

Pye, K., Tsoar, H., 1990. Aeolian Sand and Sand Dunes. Unwin Hyman Limited, London.

Pye, K., Saye, S., Blott, S., 2007. Sand dune processes and management for flood and coastal defence. Part 3: The geomorphological and management status of coastal dunes in England and Wales. R\&D Technical Report FD1302/TR. Environmental Agency (DEFRA), London.

Ratas, U., Raukas, A., Rivis, R., Tavast, E., Vilumaa, K., Anderson, A., 2012. Formation of aeolian landscapes in Estonia. In: Estonia. Geographical studies (eds. A. Raukas, K. Kukk and T. Vaaasma). Estonian Academy Publishers, Tallinn.

Ratas, U., Raukas, A., Rivis, R., Tavast, E., 2015. Aeolian activity on the northern coast of Lake Peipsi, North-Eastern Estonia. Journal of Coastal Research, 31: 25-35.

Rotnicka, J., 2011a. Factors controlling the development of foredunes along the Łeba Barrier on the south Baltic coast of Poland. Journal of Coastal Research, Special Issue, 64: 308-313.

Rotnicka, J., 2011b. Impact of beach surface type on the rate of sand transport by wind. Journal of Coastal Research, Special Issue, 64: 2058-2062.

Sergeev, A.Y., Zhamoida, V.A., Ryabchuk, D.V., Buynevich, I.V., Sivkov, V.V., Dorokhov, D.V., Bitinas, A., Pupienis, D., 2016. Genesis, distribution and dynamics of lagoon marl extrusions along the Curonian Spit, southeast Baltic Coast. Boreas, 46: 69-82.

Stankevičiūtè, J., 2006. The succession of sand vegetation of Lithuanian seacoast. Botanica Lithuanica, 12: 139-156.

Tsoar, H., Møller, J.T., 1986. The role of vegetation in the formation of linear dune. In: Aeolian Geomorphology (ed. W.G. Nickling): 75-95. Allen and Unwin, Boston.

Vermaat, J., Gilbert, A., 2006. Habitat dynamics at the catchment-coast interface: contribution from ELOISE. Environmental Sciences, 3: 15-37.

Wojtanowicz, J., 2009. Contemporary aeolian processes in Europe (in Polish with English summary). Prace i Studia Geograficzne, 41: 235-244.

Žilinskas, G., Jarmalavičius, D.D., Minkevičius, V., 2001. Eolian processes on the marine coast (in Lithuanian). Institute of Geography, Vilnius.

Žilinskas, G., Jarmalavičius, D., Damušytè, A., Pupienis, D., 2016. Where did exist Juodkrantè strait during post-Litorina. International Baltic Earth Secretariat Publication, 9: 235-239. 